\title{
TINGKAT SERANGAN DAN POPULASI HAMA KUTU PUTIH PADA BEBERAPA PERTANAMAN UBI KAYU (Manihot esculenta Crantz) DI LAMPUNG
}

\author{
INFESTATION RATE AND POPULATION OF MEALYBUG IN SEVERAL \\ OF CASSAVA (Manihot esculenta Crantz) PLANTATION \\ IN LAMPUNG
}

\author{
Sidarlin*, I G. Swibawa, A. M. Hariri dan F. X. Susilo \\ Jurusan Agroteknologi, Fakultas Pertanian, Universitas Lampung \\ JL. Prof. Dr. Soemantri Brojonegoro, No. 1 Bandar Lampung 35145 \\ Universitas Lampung, Bandar Lampung, 35145 Indonesia. \\ *Email: sidarlin93@gmail.com
}

\begin{abstract}
The research that was aimed to study the infestation rate and population of mealybug in several of cassava plantations in Lampung Province conducted from September 2017 to January 2018. Mealybug sampling was carried out in several locations in Lampung, namely South Lampung, Central Lampung, Tanjung Bintang and East Lampung. Two cassava plantation field were select in every location, and ten plant as samples were selected systematic randomized in each sampling point from every crops land. The sample were taken from five sample points located on four diagonal lines and one at the midpoint of each crop land. One plant from each sample point was selected for observation of the mealybug population. The laboratory process is carried out at the Plant Pests Laboratory, University of Lampung. The results showed that mealybug were found in all locations of observation with a low population density of 0.68-3.26 individuals per 3 leaves. Location of cassava does not affect the population of mealybug but this affects crop damage which ranges from 47 - 59\%. Crops damage in South Lampung was lower than crops damage in East Lampung and Tanjung Bintang.
\end{abstract}

Keywords: Cassava, Mealybug, South Lampung

\begin{abstract}
ABSTRAK
Penelitian yang bertujuan untuk mempelajari tingkat serangan dan populasi hama kutu putih pada beberapa lokasi penanaman ubi kayu di Provinsi Lampung berlangsung dari September 2017 sampai Januari 2018. Pengambilan sampel dilakukan di beberapa lokasi penanaman ubi kayu yaitu di lima desa pada lima kecamatan yang berada di Lampung Selatan, Lampung Tengah dan Lampung Timur. Tanaman sampel tingkat serangan adalah sepuluh tanaman yang dipilih secara sistematik, masing-masing pada lima titik sampel yang terletak di empat garis diagonal dan satu di titik tengah pada setiap lahan. Satu tanaman pada setiap titik sampel dipilih untuk pengamatan populasi kutu putih. Proses laboratorium dilakukan di Laboratorium Ilmu Hama Tumbuhan,
\end{abstract}


Jurusan Proteksi Tanaman Fakultas Pertanian, Universitas Lampung. Hasil penelitian menunjukkan bahwa kutu putih ditemukan di semua lokasi pengamatan dengan kepadatan populasi yang rendah yaitu 0,68-3,26 indiv. per 3 daun. Lokasi penanaman ubi kayu tidak mempengaruhi populasi kutu putih tetapi lokasi ini mempengaruhi kerusakan tanaman yang berkisar $47-59 \%$. Kerusakan tanaman di Lampung Selatan lebih rendah daripada kerusakan tanaman di Lampung Timur dan Tanjung Bintang.

Kata Kunci : Hama kutu daun, Lampung selatan, singkong

\section{PENDAHULUAN}

Ubi kayu (Manihot esculenta Crantz) adalah tanaman pangan yang cocok ditanam di berbagai wilayah di Indonesia termasuk Sumatera. Ubi kayu mudah beradaptasi pada lahan yang marginal dan beriklim kering.

Ubi kayu merupakan tanaman pangan penting dan komoditas penghasil devisa. Ubi kayu termasuk tanaman pangan penting urutan ketiga setelah padi dan jagung di Indonesia (Thamrin et al., 2013). Sebagai bahan pangan, ubi kayu memiliki keunggulan yaitu kandungan gizi yang cukup tinggi. Dalam $100 \mathrm{~g}$ umbi ubi kayu terkandung kalori 146 k.kal, protein 1,5 g, lemak $0,7 \mathrm{~g}$, karbohidrat $81,3 \mathrm{~g}$, fosfor $0,06 \mathrm{~g}$, zat besi 0,02 g, dan vitamin B1 0,04 g (Direktorat Gizi Departemen Kesehatan RI, 1989). Ubi kayu menghasilkan devisa negara melalui ekspor dalam bentuk olahan (Darjanto dan Murjati, 1980 dalam Wahyudi, 2009).

Berdasarkan data Badan Pusat Statistik(BPS) tahun 2016 luas panen dan produksi ubi kayu di Lampung dalam kurun waktu 4 tahun mengalami penurunan. Seperti yang disajikan pada Gambar 1, luas panen dan produksi ubi kayu sejak tahun 2012 sampai dengan tahun 2015 menurun tajam.
Salah satu penyebab rendahnya produksi ubi kayu adalah organisme pengganggu tanaman (OPT). OPT penting pada tanaman ubi kayu adalah kutu putih. Kutu putih yang sangat merusak ubi kayu adalah Phenacoccus manihoti yang merupakan hama invasif berasal dari Amerika Selatan (Rauf, 2011). Populasi hama ini sangat cepat meningkat karena reproduksinya bersifat partenogenetik teliotoki yaitu semua keturunan yang dihasilkan adalah betina. Serangan kutu putih ubi kayu dapat menurunkan produksi ubi kayu sampai 90\% (Neuenschwander et al., 1991).

Produksi ubi kayu di Lampung dapat terancam olah serangan hama kutu putih. Namun demikian, sulit ditemukan informasi mengenai serangan kutu putih pada pertanaman ubi kayu di Lampung. Oleh karena itu, kajian mengenai populasi dan tingkat serangan hama kutu putih pada pertanaman ubi kayu di Lampung perlu di lakukan. Penelitian ini bertujuan untuk mempelajari populasi dan tingkat serangan hama kutu putih pada beberapa lokasi penanaman ubi kayu di Lampung.

\section{BAHAN DAN METODE}

Penelitian dilaksanakan pada beberapa areal pertanaman ubi kayu di Provinsi Lampung, yaitu Lampung Selatan, Lampung Tengah, Lampung Timur 


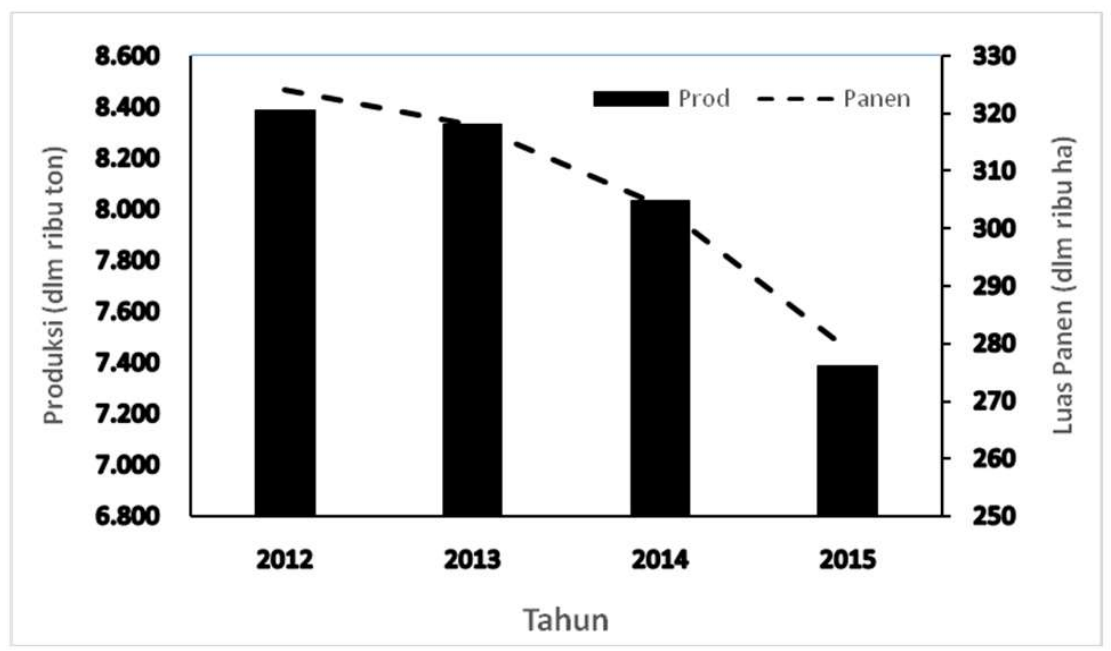

Gambar 1. Produksi dan luas panen ubi kayu di Lampung tahun 2012-2015 (BPS, 2016).

dan Tanjung Bintang. Proses laboratorium dilakukan di Laboratorium Ilmu Hama Tumbuhan, Jurusan Proteksi Tanaman Fakultas Pertanian, Universitas Lampung. Penelitian berlangsung sejak bulan September 2017 sampai bulan Januari 2018.

Di Lampung Selatan, pengambilan sampel dilakukan di dua areal pertanaman ubi kayu yang berada di Kecamatan Natar dengan posisi geografi 5¹6’49,5912" LS dan 105¹2’152.8912" BT pada pertanaman klon UJ3 berumur 7 bulan seluas $3241 \mathrm{~m}^{2}$ dengan populasi 5832 tanaman. Areal kedua yaitu pertanaman ubikayu klon UJ3 berumur 4 bulan seluas $7697 \mathrm{~m}^{2}$ dengan populasi tanaman 11076 tanaman dan terletak pada posisi geografi $5^{\circ} 17^{\prime} 43.368^{\prime \prime}$ LS 105¹2’43.11" BT. Di Lampung Lampung Tengah pengambilan sampel dilakukan di dua lokasi yaitu pada pertanaman ubi kayu UJ3 berumur 5 bulan dengan luas areal $8732 \mathrm{~m}^{2}$ dan populasi tanaman 13176 tanaman yang terletak pada posisi geografi $4^{\circ} 57^{\prime} 18.9468^{\prime \prime} \mathrm{LS}$ dan $105^{\circ} 1$ '15.2292" BT serta pertanaman ubi kayu UJ3 berumur 7 bulan seluas $12385 \mathrm{~m}^{2}$ dengan populasi tanaman 19110 tanaman yang terletak pada posisi geografi $4^{\circ} 57^{\prime} 35.1972^{\prime \prime}$ LS dan 1050'57.456" BT. Di Lampung Timur sampel diambil di dua lokasi yaitu pertanaman ubi kayu UJ3 berumur 12 bulan seluas $14582 \mathrm{~m}^{2}$ dengan populasi tanaman 21733 tanaman yang terletak pada posisi geografi 504'84.599" LS dan 105'4'16.8784" BT dan pertanaman ubi kayu UJ5 berumur 6 bulan seluas $4873 \mathrm{~m}^{2}$ dengan populasi tanaman 6916 tanaman yang terletak pada posisi geografi 5²'36.4008" LS dan 105²4’20.8944" BT. Di Tanjung Bintang sampel diambil pada kebun ubi kayu UJ5 berumur 9 bulan luas $5000 \mathrm{~m}^{2}$ dengan populasi 1554 tanaman berposisi geografi $5^{\circ} 23^{\prime} 42,486^{\prime \prime}$ LS dan $105^{\circ} 22^{\prime} 1,6212^{\prime \prime}$ BT serta pertanaman ubikayu UJ3 seluas $25.000 \mathrm{~m}^{2}$ dengan populasi tanaman 12702 tanaman yang berposisi geografi $5^{\circ} 23^{\prime} 45.942^{\prime \prime}$ LS dan $105^{\circ} 22^{\prime} 10,7112^{\prime \prime}$ BT.

Tanaman sampel pada setiap areal pertanaman dipilih pada lima titik sampel yang terletak di empat garis diagonal dan satu di titik tengah. Pada setiap titik sampel diambil dua baris tanaman yang berada di 
sebelah kanan dan kiri titik sampel. Dalam setiap baris tanaman dipilih sepuluh tanaman sampel secara sistematik. Tanaman yang berada bertepatan dengan titik sampel adalah tanaman sampel pertama, selanjutnya dipilih sembilan tanaman lainya dalam baris tersebut. Pada 5 tanaman sampel ini diamati tingkat serangan kutu putih. Kemudian, dari lima tanaman tersebut dipilih satu tanaman secara acak untuk pengamatan populasi kutu putih. Pada satu tanaman sampel terpilih ini diambil sampel daun untuk pengamatan populasi kutu putih. Sampel daun diambil pada zona bagian pucuk, tengah dan bawah tanaman, masing-masing sebanyak tiga daun pada setiap zona, kemudian dimasukkan ke dalam kantong plastik $2 \mathrm{~kg}$, diberi label, kemudian dibawa ke laboratorium untuk diproses.

Pengamatan tingkat serangan dilakukan secara visual berdasarkan gejala serangan. Serangan kutu putih menunjukkan gejala yaitu pada bagian atas tanaman menjadi kerdil atau "bunchy top", daun mengeriting dan terjadi distorsi pada batang. Kerusakan tanaman yang disebabkan oleh kutu putih diberi skor 0 untuk tanaman tidak terserang, skor 1 untuk tanaman terserang sedang dan skor 2 untuk tanaman terserang berat (Gambar 2). Intensitas kerusakan tanaman dihitung dengan menggunakan rumus:

$$
\mathrm{I}=\left[\left(\sum \mathrm{n}_{\mathrm{i}} \cdot \mathrm{v}_{\mathrm{i}}\right) / \mathrm{N} . \mathrm{V}\right] \times 100 \%
$$

dimana:

$\mathrm{I}=$ intensitas kerusakan,

$\mathrm{n}_{\mathrm{i}}=$ jumlah tanaman dalam setiap kategori skor,

$\mathrm{v}_{\mathrm{i}}=$ kategori skor,

$\mathrm{N}=$ jumlah tanaman dalam satu titik pengamatan, dan $\mathrm{V}=$ nilai skor tertinggi

\section{HASIL DAN PEMBAHASAN}

Ada dua jenis kutu putih yang menyerang tanaman ubi kayu di Lampung yaitu kutu putih ubi kayu (Phenacoccus manihoti) dan kutu putih pepaya (Paracoccus marginatus). Hasil pengamatan menunjukkan bahwa semua lokasi pertanaman ubi kayu diserang hama kutu putih. Populasi hama ini masih rendah yaitu berkisar 0,68 -3,26 individu / 3 daun (Tabel 2).

Data ini menunjukkan bahwa hama kutu putih pada pertanaman ubi kayu telah menyebar pada berbagai lokasi pertanaman ubi kayu di Lampung. Kutu putih ubi kayu (P. manihoti) juga dilaporkan telah menyebar hampir di seluruh lokasi panen ubi kayu di Pulau Jawa. Dari 35 titik lokasi survei, kutu putih $P$.

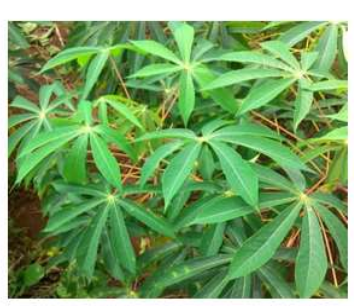

Skor 0

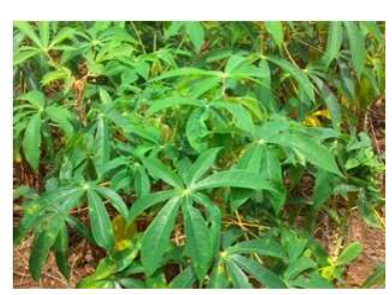

Skor 1

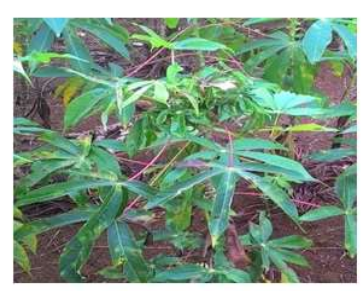

Skor 2

Gambar 2. Tingkat kerusakan tanaman dari skor 0 sampai skor 2 
manihoti dan gejala serangannya dijumpai pada pertanaman ubi kayu di 22 lokasi yang tersebar di Jawa Barat (10 lokasi), Jawa Tengah (7 lokasi), dan Jawa Timur (5 lokasi) (Abdulchalek et al., 2017).

Analisis ragam menunjukkan bahwa lokasi penanaman ubi kayu tidak mempengaruhi populasi kutu putih $(\operatorname{Pr}>F=0,19)$. Populasi kutu putih di Lampung Tengah sebesar 0,68 indiv. / 3 daun tidak berbeda dengan populasi kutu putih di Lampung Timur yaitu sebesar 3,26 indiv. /3 daun. Demikian juga, populasi kutu putih di Lampung Selatan dan Tanjung Bintang tidak berbeda yaitu berturutan 1,26 dan 3,25 indiv. / 3 daun. (Tabel 1). Hasil penelitian ini sejalan dengan hasil penelitian Abdulchalek (2017) yang menunjukkan populasi kutu putih ubi kayu antar lokasi tidak berbeda, dengan kepadatan populasi 4,82 - 4,51 ekor per tanaman. Pertanaman yang sebelumnya pernah terserang oleh P. manihoti dapat dikenali oleh adanya bagian-bagian buku yang memendek atau adanya distorsi pada batang.

Pada tanaman ubi kayu, populasi kutu putih dipengaruhi $(\operatorname{Pr}>\mathrm{F}=0,0004)$ oleh zona posisi daun tanaman. Populasi kutu putih lebih tinggi pada zona daun bawah daripada zona daun di pucuk dan tengah. Populasi kutu putih pada zona daun pucuk yaitu 0,16 individu/3 daun tidak berbeda dengan populasi kutu putih pada zona daun tengah yaitu 1,76 individu/3 daun. Populasi kutu putih pada kedua zona daun ini nyata lebih rendah daripada populasi kutu putih pada zona daun bawah yaitu 4,96 indiv. / 3 daun (Tabel 2). Hasil penelitian ini berbeda dengan laporan Rizky (2018) yang menemukan populasi kutu putih pada pertanaman ubi kayu lebih banyak pada zona daun bagian atas. Perbedaan kepadatan populasi antar zona posisi daun dapat dikarenakan oleh faktor curah hujan. Kutu putih ubikayu(P. manihoti) menyukai bagian pucuk tanaman

Tabel 1. Populasi kutu putih pada berbagai lokasi penanaman ubi kayu di Lampung

\begin{tabular}{lc}
\hline Lokasi & Individu/ 3 daun \\
\hline Lampung Selatan & $1,26 \mathrm{a}$ \\
Lampung Tengah & $0,68 \mathrm{a}$ \\
Lampung Timur & $3,26 \mathrm{a}$ \\
Tanjung Bintang & $3,25 \mathrm{a}$ \\
\hline BNT & 2,72 \\
\hline
\end{tabular}

Keterangan: data yang diikuti huruf yang sama tidak berbeda menurut uji BNT pada taraf nyata $5 \%$.

Tabel 2. Populasi kutu putih pada 3 zona daun tanaman ubi kayu

\begin{tabular}{lc}
\hline Zona daun & Individu/3 daun \\
\hline Bagian Pucuk & $0,16 \mathrm{~b}$ \\
Bagian Tengah & $1,76 \mathrm{~b}$ \\
Bagian Bawah & $4,96 \mathrm{a}$ \\
\hline BNT & 2,35 \\
\hline
\end{tabular}

Keterangan: data yang diikuti huruf yang sama tidak berbeda menurut uji BNT pada taraf nyata $5 \%$. 
Tabel 3. Intensitas kerusakan tanaman tersebab kutu putih pada beberapa lokasi penanaman ubi kayu di Lampung

\begin{tabular}{lc}
\hline Lokasi & Intensitas kerusakan (\%) \\
\hline Lampung Selatan & $47,00 \mathrm{~b}$ \\
Lampung Tengah & $54,75 \mathrm{ab}$ \\
Lampung Timur & $59,00 \mathrm{a}$ \\
Tanjung Bintang & $58,75 \mathrm{a}$ \\
\hline BNT & 7,81 \\
\hline
\end{tabular}

Keterangan: data yang diikuti huruf yang sama tidak berbeda menurut uji BNT pada taraf nyata $5 \%$.

ubi kayu, tetapi apabila terjadi hujan (bulan September 2017 - Januari 2018) maka tubuh kutu putih pada bagian pucuk dapat terjatuh atau hanyut yang disebabkan air hujan, akibatnya kutu putih lebih banyak yang ditemukan di zona bagian bawah.

Tingkat serangan kutu putih pada pertanaman ubi kayu dalam penelitian ini dinyatakan dengan intensitas kerusakan tanaman. Hasil pengamatan menunjukkan bahwa intensitas kerusakan tanaman ubi kayu di Lampung berkisar 47 - 59\% (Tabel 3). Lokasi penanaman ubi kayu nyata berpengaruh terhadap intensitas kerusakan tanaman yang disebabkan oleh kutu putih $(\operatorname{Pr}>F=0,04)$. Kerusakan tanaman ubi kayu di Lampung Selatan sebesar 47\% lebih rendah daripada kerusakan tanaman ubi kayu di Lampung Timur dan Tanjung Bintang yaitu berturutan 59,00 dan 58,75 \%. Kerusakan tanaman ubi kayu di Lampung Selatan tidak berbeda dengan kerusakan tanaman ubi kayu di Lampung Tengah yaitu 47\% dan 54,75\%. (Tabel 4). Intensitas kerusakan tanaman pada penelitian ini lebih rendah dibandingkan intensitas kerusakan tanaman ubi kayu yang dilaporkan Agustin (2017) yang menyebutkan tingkat kerusakan ubi kayu kerena serangan kutu putihmencapai 70,6\%. Keberadaan kutu putih mempengaruhi intensitas kerusakan tanaman, semakin padat populasi hama maka intensitas kerusakan tanaman semakin tinggi (Agustin, 2017).

\section{KESIMPULAN}

Hama kutu putih ditemukan pada semua lokasi penanaman ubi kayu di Lampung, tetapi populasinya rendah yaitu berkisar 0,68 -3,26 indiv. per 3 daun dengan intensitas kerusakan tanaman 47 - 59\%. Populasi kutu putih tidak berbeda, tetapi intensitas kerusakan tanaman berbeda antar lokasi penanaman. Kerusakan tanaman di Lampung Selatan lebih rendah daripada kerusakan tanaman di Lampung Timur dan Tanjung Bintang

\section{DAFTAR PUSTAKA}

Agustin, Y. 2017. Intensitas Serangan dan Populasi Kutu Putih Serta Tungau Merah Pada 11 Klon Ubikayu (Manihot esculenta Crantz). Skripsi. Fakultas Pertanian Universitas Lampung. Lampung. $52 \mathrm{hlm}$.

Abdulchalek, B., Rauf, A. dan Pudjianto. 2017. Kutu Putih Singkong, Phenacoccus manihoti Matile-Ferrero (Hemiptera: Pseudococcidae): 
Persebaran Geografi di Pulau Jawa dan Rintisan Pengendalian Hayati. J. HPT Tropika. 17(1):1-8.

Badan Pusat Statistik [BPS] RI. 2016. Produksi Ubi Kayu . http://www.bps.go.id/linkTableDinamis/ view/id/880. Diunduh pada 10 Februari 2017.

Direktorat Gizi Departemen Kesehatan RI. 1989. Daftar Komposisi Bahan Makanan. Bharata : Jakarta.

Neuenschwander P, Borowka R, Phiri G, Hammans H, Nyirenda S, Kapeya E.H. \& Gadabu A. 1991. Biological control of the cassava mealybug Phenacoccus manihoti (Hom., Pseudococcidae) by Epidinocarsis lopezi (Hym ., Encyrtidae) in Melawi. Biocontrol Science and Technology 1: 297-310.
Rauf, A. 2011. Invasive Pests . IPM CRSP Annual Report 2010-2011. $100 \mathrm{hlm}$.

Rizky, M. 2018. Intensitas Serangan dan Populasi Hama Utama pada Ubi Kayu (Manihot esculenta Crantz) dengan Perlakuan Pupuk Zincmikro. Skripsi. Fakultas Pertanian Universitas Lampung. Lampung. $41 \mathrm{hlm}$.

Thamrin, M., Mardhiyah, A. dan Marpaung, S.E. 2013. Analisis usaha tani ubi kayu (Manihot utilissima). Agrium 18(1): 57-64.

Wahyudi. 2009. Karakterisasi pati ubi kayu (Manihot esculenta Crantz) varietas Mentega untuk pembuatan edible film dengan penambahan sodium Tripolyphosphate (stpp). Skripsi. Universitas Sebelas Maret. Surakarta. 50 hlm. 